\title{
Prosztatarákban szenvedő betegek definitív ellátásának tanulságai és modern stratégiái
}

\author{
Varga Linda dr. ${ }^{1}$ - Bajory Zoltán $d r_{.}{ }^{2}$ - Pajor László dr. ${ }^{2}$ \\ Révész János dr. ${ }^{4}$. Sükösd Farkas dr. ${ }^{3}$ - Maráz Anikó dr. ${ }^{1}$ \\ Szegedi Tudományegyetem, Általános Orvostudományi Kar, \\ ${ }^{1}$ Onkoterápiás Klinika, ${ }^{2}$ Urológiai Klinika, ${ }^{3}$ Pathologiai Intézet, Szeged \\ ${ }^{4}$ Borsod-Abaúj-Zemplén Megyei Központi Kórház és Egyetemi Oktató Kórház, Onkoterápiás Centrum, Miskolc
}

\begin{abstract}
Bevezetés: A korszerü diagnosztikus és kezelési lehetőségek igénybevételével a prosztatarák mortalitása jelentősen csökkenthető. A korai stádiumú daganatos betegek radikális mútéttel vagy sugárkezeléssel is meggyógyíthatók. Célkitüzés: A jelenlegi kivizsgálási és a terápiás módszerek áttekintése és összehasonlítása a korábbi gyakorlattal a diagnózis pontossága, a hatékonyság javítása és a mellékhatások csökkentése szempontjából, valamint általános összefüggések megvilágítása súlyos szövődményes esetek kapcsán.

Módszer: Két prosztatadaganatos eset mentén ismertetjük a pontos szövettani diagnózis jelentőségének és változásának, a megfelelő képalkotó vizsgálatok alkalmazásának, a besugárzás hagyományos és modern paramétereinek, valamint a sugárkezelés akut és késői szövődményeinek részleteit. Elemzésre kerülnek a korábbi és a napjainkban alkalmazott módszerek lényegi különbségei és ezek konzekvenciái is.

Eredmények: Betegeink diagnózisában napjainkra módosult a szövettani vélemény. Mindkét esetben 2009-2011-ben hagyományos, 3 dimenziós konformális technikával definitív sugárkezelés történt, melynek hatására meggyógyultak prosztatatumorukból. Az egyik beteg besugárzást kapott a hólyagra is, mivel a daganat beszúrte azt. A másiknál a biztonsági zóna kiterjesztése miatt, a kor színvonalán álló besugárzás a hólyagalapot is kiterjedtebben érintette. Bár mindkét esetben hetek alatt szanálódott a hevenyen jelentkező kettes fokozatú cystitis, mégis késői szövődményként zsugorhólyag alakult ki. Ezek elhárítására - az első esetben a vérzés megállítására, a második esetben az incontinentia megszüntetésére - a hagyományos eljárások kudarca miatt radikális cystoprostatectomiára volt szükség.

Következtetések: A prosztatadaganatok diagnosztikai és terápiás fejlődésének összetett lépései együttesen vezetnek a súlyos szövődmények elkerüléséhez. Az adatok szintézise azonban akkor lehet még sikeresebb, ha azokat a korábbi tapasztalatok birtokában is elemezzük.
\end{abstract}

Orv Hetil. 2018; 159(32): 1317-1325.

Kulcsszavak: prosztatarák, Gleason-pontszám, multiparametrikus MRI, modern sugárkezelés, mellékhatások

\section{Edifications and modern strategies of localized prostate cancers' definitive therapy}

Introduction: Mortality of prostate carcinoma can be significantly decreased by the use of modern diagnostic and therapeutic options. Patients in early stages can be cured by radical surgery or radiotherapy.

Aim: Overview and comparison of previous and present diagnostic and therapeutic methods regarding accuracy of diagnosis, improvement of efficiency and decrease of toxicities. We also aimed to explore general correlations in case of serious complications.

Method: By the help of two prostate cancer patients we demonstrate the importance of accuracy and change of histological diagnosis, significance of proper imaging techniques, and also show parameters of conventional and modern radiotherapy and their acute and chronic complications. Differences of previous and present methods and their consequences were analyzed.

Results: By now, histological findings in the patients' diagnosis have changed. Both patients received conventional three-dimensional definitive radiotherapy in 2009-2011, and their prostate cancer was cured. In one case, urinary bladder also received radiotherapy because prostate carcinoma had infiltrated it. In the other case, the contemporary radiotherapy involved urinary bladder's fundus due to safety margins. Although acute grade 2 cystitis developed in 
both cases and recovered in several weeks, as late complication bladder shrinkage developed, which after the ineffectiveness of conventional therapies had to be cured by radical cystoprostatectomy - in order to cease bleeding and to cure incontinence.

Conclusions: In case of prostate carcinomas, serious complications can be avoided by the improvement of diagnostic and therapeutic options. Synthesis of data could be more successful if they were analyzed in the light of previous experiences.

Keywords: prostate cancer, Gleason score, multiparametric MRI, modern radiotherapy, side effects

Varga L, Bajory Z, Pajor L, Révész J, Sükösd F, Maráz A. [Edifications and modern strategies of localized prostate cancers' definitive therapy]. Orv Hetil. 2018; 159(32): 1317-1325.

(Beérkezett: 2018. február 26.; elfogadva: 2018. március 16.)

\begin{abstract}
Rövidítések
3D $=3$ dimenziós; ACR $=($ American College of Radiology $)$ Amerikai Radiológiai Társaság; $\mathrm{ADT}=$ androgén deprivatiós terápia; $\mathrm{CK}=$ citokeratin; $\mathrm{CT}=$ (computed tomography) számítógépes tomográfia; ESUR = $($ European Society of Uroradiology) Európai Uroradiológiai Társaság; ${ }^{68} \mathrm{Ga}$-PSMA-PET = (positron emission tomography with gallium-labelled prostate specific membrane antigen) pozitronemissziós tomográfia galliumjelölt prosztataspecifikus membránantigénnel; $\mathrm{HE}=$ hematoxilin-eozin; IGRT = (image-guided radiotherapy) képvezérelt besugárzás; IM = intenzitásmodulált; ISUP = (International Society of Urological Pathology) Nemzetközi Urológiai Kórbonctani Társaság; $\mathrm{mpMRI}=$ (multiparametric magnetic resonance imaging) multiparametrikus mágneses rezonanciás vizsgálat; $M R I=$ mágneses rezonanciás vizsgálat; $P C$ $=($ prostate cancer $)$ prosztatarák; PSA = prosztataspecifikus antigén; TRUH = transrectalis ultrahang; TUC = transuretralis koaguláció; TUR = transuretralis reszekció
\end{abstract}

A prosztatarák (PC) világszerte a férfiak második leggyakrabban diagnosztizált rosszindulatú betegsége, daganat okozta halálozásban a második helyen áll. Magyarországon 3000 feletti új beteget diagnosztizálnak évente $[1,2]$. Az 5 éves túlélés a korai stádiumban körülbelül $90 \%$, a metasztázissal rendelkezőknél $30 \%$ alatti $[3]$. Az adekvát gyógyszeres vagy sebészi kasztráció és lokális ellátás ellenére a betegek több mint $40 \%$-a válik áttétessé [2].

A diagnosztikus és terápiás lehetőségek fejlődésének hatására a nyugati országokban a PC okozta mortalitás csökken, ha időben történik radikális mütét vagy sugárterápia [4]. Jelentôs a multiparametrikus mágneses rezonanciás vizsgálat (mpMRI) tudatos alkalmazása a primer tumor kezdeti felismerésében és a követésben [5]. A lokális terjedés és a csontmetasztázisok kimutatásában ugyancsak az egyik leghatékonyabb eszköz az MRI. A stádium pontosításában és a recidívák diagnosztikájában a hagyományos képalkotók mellett a legújabb izotópos módszerek, mint a kolin- vagy ${ }^{68} \mathrm{Ga}$-PSMA-PET (pozitronemissziós tomográfia galliumjelölt prosztataspecifi- kus membránantigénnel) vizsgálatok a fejlődés új irányai [6-9], bár hazánkban egyelőre limitáltan érhetők el.

A prosztatadaganat szövettani malignitásfokozatának (grading) meghatározása 2014-ben megújult. Bevezetésre került az International Society of Urological Pathology (ISUP) rendszere, mely a hagyományos $5+5$ pontos Gleason-féle grading altípusainak pontosítása mellett 5 pontos úgynevezett ISUP-score-ban is rendszerezte a prostataadenocarcinomák szövettani alcsoportjait, és ezek mellé túlélési rizikócsoportokat rendelt [10].

A diagnosztikus módszerek újdonságain túl a PC terápiás lehetőségeinek palettája is jelentősen bővült. Új mütéti eljárások, laparoszkópia, idegkímélet, protézisek beültetése, pontos apicalis preparálás, müsphincterek alkalmazása került bevezetésre [11-13]. Az új módszerekkel csökkenthető a incontinentia előfordulása, biztosítva a mind teljesebb életminőség visszaállítását [1113]. Mindazonáltal bizonyított, hogy besugárzás után ezek a kritikus szövődmények kevésbé fordulnak elő [10-12, 14].

A besugárzási módszerek is robbanásszerű technikai fejlődést mutatnak. Az intenzitásmodulált (IM) és képvezérelt irradiáció (image-guided radiotherapy - IGRT) [15], akár a stereotaxiás vagy cyberkéssel végzett ablatív sugársebészeti módszerek már hazánkban is elérhető technikák, melyek lehetővé teszik a kuratív dózis leadásának növelését, a védendő szervek besugárzási dózisának és a potenciális mellékhatásoknak a csökkentése mellett $[14,16]$.

A szövettanilag igazolt, lokoregionális prosztatarákok definitív kezelésére mind a mütét, mind a besugárzás világszerte rendelkezésre áll. Mivel magas arányban gyógyulás érhető el bármelyik módszerrel, megengedhető, hogy a beteg maga válassza meg a számára leginkább megfelelő eljárást [17].

Közepes és magas rizikójú esetekben a kezelési lehetőségek közé kiegészítésként a hormonkezelést (androgén deprivatiós terápia - ADT) is be kell illeszteni, mely intermedier rizikó esetén a definitív sugárkezelés előtt (és 
alatt) 4-6 hónapos neoadjuváns indikációban, magas rizikójú betegség esetén (Gleason: 8-10, prosztataspecifikus antigén [PSA] 20 felett vagy lokálisan kiterjedt T3bT4-es stádium) a sugárkezeléssel szinkrón indul, 24-36 hónapon át indikált [4]. Egyre több adat szól amellett, hogy a magas rizikójú, lokálisan előrehaladott betegek adekvát sebészi kezelése esetén az ADT alkalmazásának haszna leginkább a nyirokcsomó-pozitív esetekben igazolható [18].

A kedvező túlélési eredmények hozták előtérbe a szövődmények kérdését is, hogy milyen gyakorisággal fordulnak elő, és mennyire fogják zavarni a gyógyult emberek életminőségét. Sajnos ezek kevésbé igazak a magas kockázatú esetekre, hiszen itt mindig a célszerü kombinált kezelés, a multimodális megközelítés a fontos - akár magasabb szövődmények árán - a gyógyulás érdekében $[4,19,20]$.

Dolgozatunkban két eset mentén tekintjük át a diagnosztika és a terápia korábbi és jelen módszereinek hatékonyságát, különös tekintettel a mellékhatások csökkentésére, és használjuk fel azokat általános összefüggések elemzésére azért, hogy minél kevesebb súlyos szövődmény - akár zsugorhólyag - forduljon elő a mindennapi hazai gyakorlat során.

\section{Betegek és módszer}

\section{Az elsö beteg}

Kiindulási adatok: Egy 54 éves férfi vizsgálata 2009-ben dysuriás panaszok miatt indult, melyek gyógyszeres kezelésre (tamszulozin, finaszterid, antibiotikum) nem javultak. Több társbetegségben szenvedett, mint inzulindependens cukoranyagcsere-zavar és magasvérnyomás-betegség. Induló PSA-értéke $1,70 \mathrm{ng} / \mathrm{ml}$, ez és a normális tapintási lelet nem jelzett prosztatarákot. Pana-

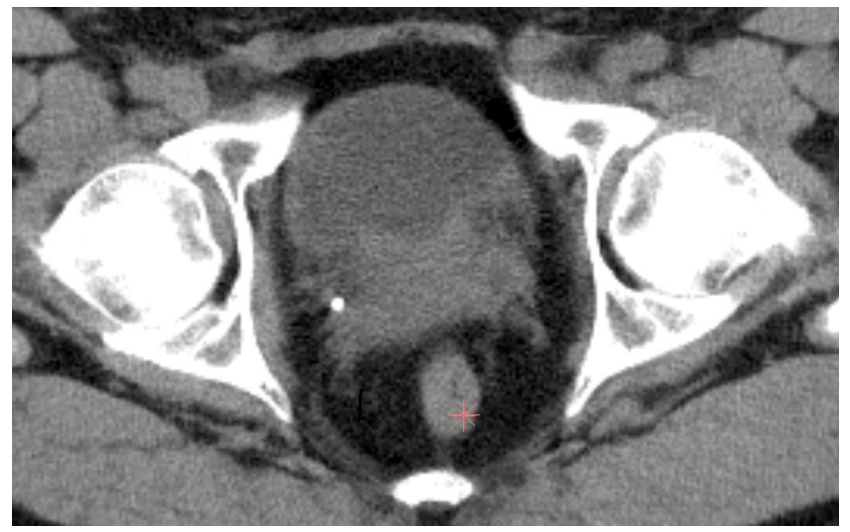

1. ábra | Primer diagnosztikus CT, a prosztatatumor hólyagra terjedése

szait a transrectalis ultrahang (TRUH) szerint középlebeny okozta, ezért előkészítés után transuretralis reszekció (TUR) történt. A hólyagban a beavatkozás során daganat vagy prosztatarák hólyagra terjedése nem látszott. Meglepetést jelentett a szövettani eredmény, mely prostataadenocarcinomát igazolt, a reszekátum 10-12\%át elfoglalta, tehát minimum pTlb, Gleason: $2+3=5$. A stádium felmérésére készült számítógépes tomográfia (CT) a vesék részérôl eltérést nem mutatott, pangás nem ábrázolódott, viszont a hólyagfal megvastagodott volt, a prosztatától nem volt elkülöníthető; maga a prosztata nem volt nagyobb, benne fokozott denzitás nem volt. A kép a radiológiai leírás szerint felvetette a prosztatadaganat hólyagra terjedését (1. ábra), a stádium így cT3-ra módosult [21] (2. ábra). A csontszcintigráfia negatív volt.

Terápiás döntés: A hólyagra terjedés képalkotó diagnózisa alapján a magas rizikójú betegség miatt radikális prostatectomia helyett definitív besugárzás és ADT volt a tervezett terápia 2009-ben. A tervezési CT-n is igazo-

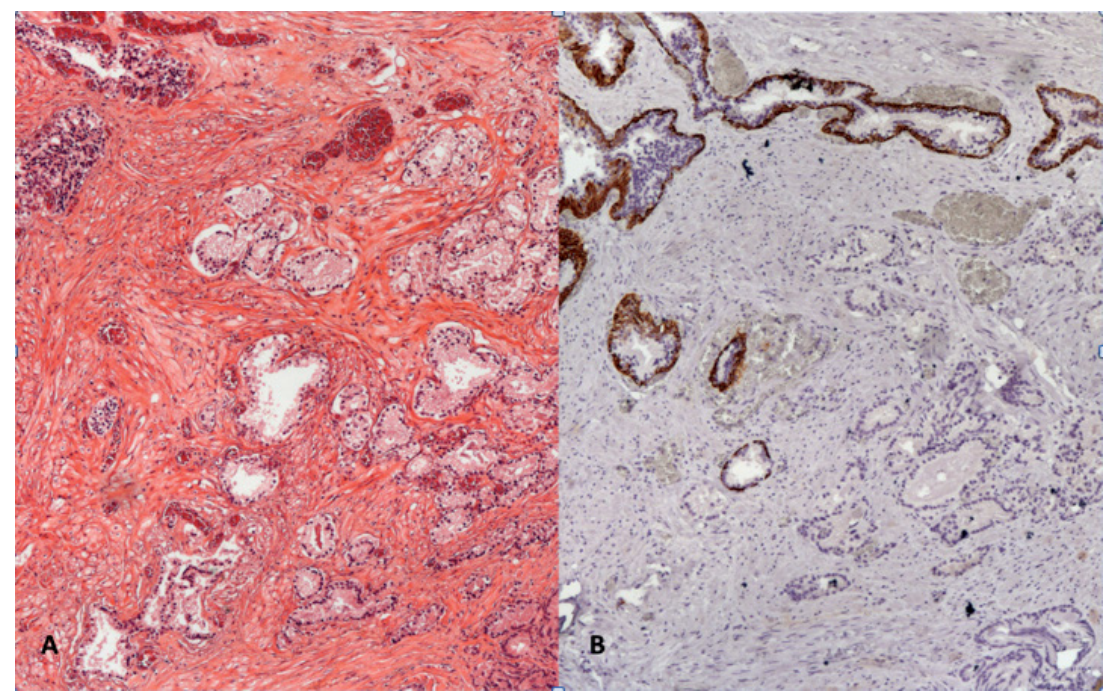

2. ábra

A TUR-reszekátum alapján Gleason szerinti $3+4$, legalább pTlb volt megállapítható. Újraértékelve a mintákat, a húgyhólyagfalat is infiltrálta a da ganat. A: A bal felső sarokban mintavételi károsodást szenvedett, de daganatmentes, belső kontrollként szolgáló mirigyek láthatók (HE-festés, 20× nagyítás). B: A mélyebb síkból származó képen a tumoros mirigyek bazális sejtrétegsoruk elvesztése miatt nem mutatják a CK5/6-os festődést, míg a normális kontrollmirigyek igen (CK5/6-os festés, 20× nagyítás) 


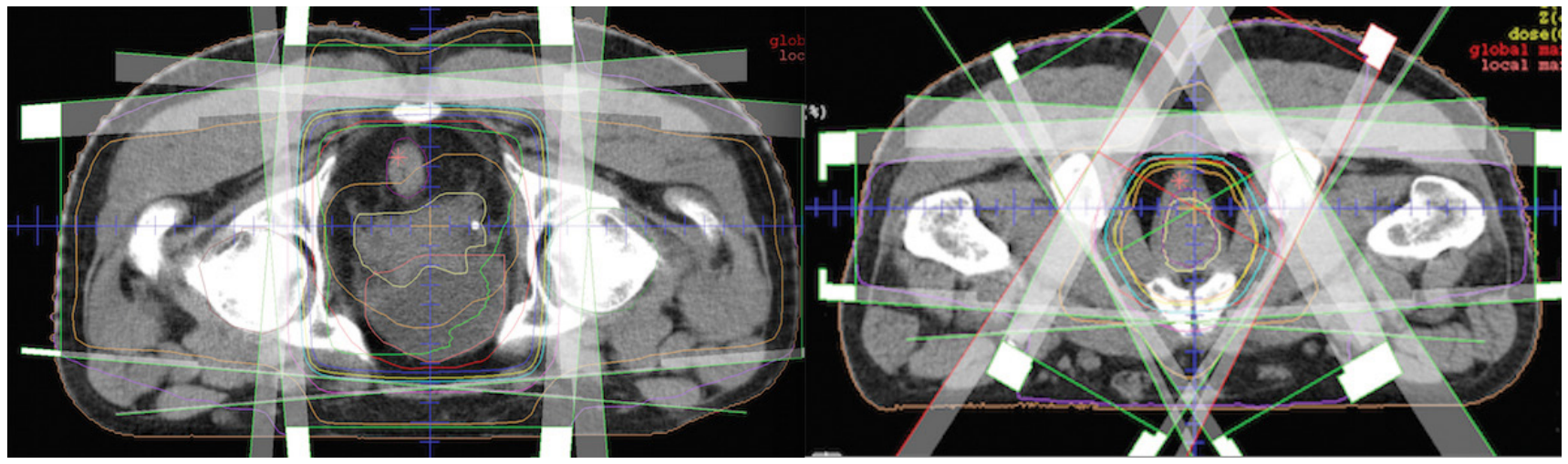

3. ábra

A sugárkezelés céltérfogatai, besugárzási mezők és izodóziseloszlások - 4 mezős boxtechnikás besugárzás (balról) és a kiegészítő 6 mezős boost keze lés (jobbról)

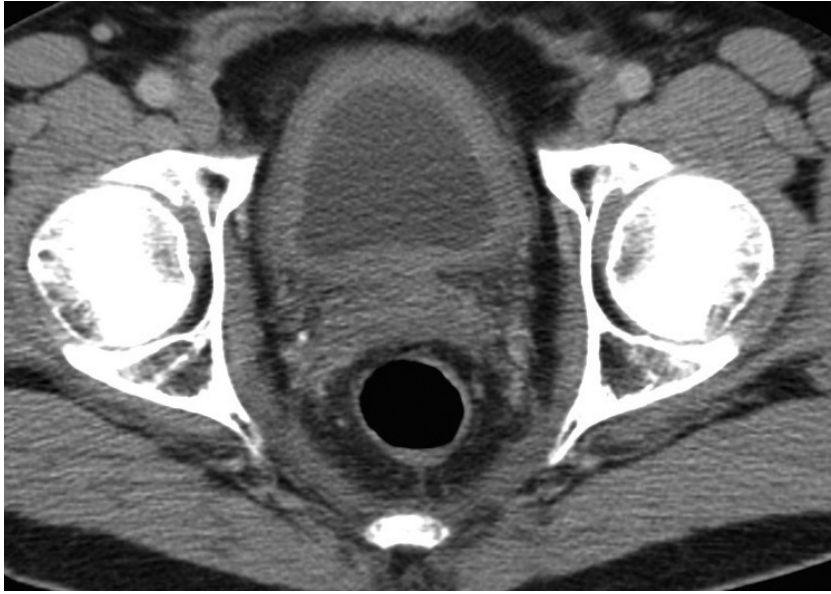

4. ábra

| Sugárkezelés utáni CT-kontroll a megvastagodott hólyagfallal

lódott a hólyagra terjedés gyanúja, ezért a húgyhólyag is a célterület részét képezte (átlagos besugárzási dózisa 60,5 Gy, maximális dózisa 69,7 Gy) a kismedencei nyirokrégiók, a prosztata és a vesicula seminalisok mellett, 45 Gy összdózisban, 1,8 Gy napi frakciókkal, majd a prosztatára további $15 \times 1,8$ Gy dóziskiegészítés történt az akkoriban hazánkban korszerúnek tekinthető konformális technikával, lineáris gyorsítóval (3. ábra).

Mellékbatások: A sugárkezelés során akutan grade 2-es urogenitalis és grade 1-es gastrointestinalis mellékhatások [22] jelentek meg gyakori vizelés és székletürítés formájában, melyek idővel, hónapok alatt javultak. 2011 májusában a hátsó húgycső beszúküult, ez TUR során került ellátásra. A CT-vizsgálat megvastagodott hólyagfalat írt le (4. ábra). A TUR szövettana sem prosztata-, sem hólyagdaganatot nem igazolt, csak sugárkárosodást. A mútétből a beteg felgyógyult, majd vérzés indult a hólyagból. Ennek kezelésére ismételt TUR és TUC (transuretralis koaguláció) történt, kétoldali hólyagér-embolisatióval (az arteria femoralison és az iliaca internán át a vesicalis superiorban és inferiorban végzett vérzéscsillapító célú katéteres embolisatio) és összesen 22 egység vér transzfúziójával. Közben a vesékben pangás keletkezett, a szérumkreatinin $405 \mathrm{mmol} / \mathrm{l}$-re emelkedett. Az átme-

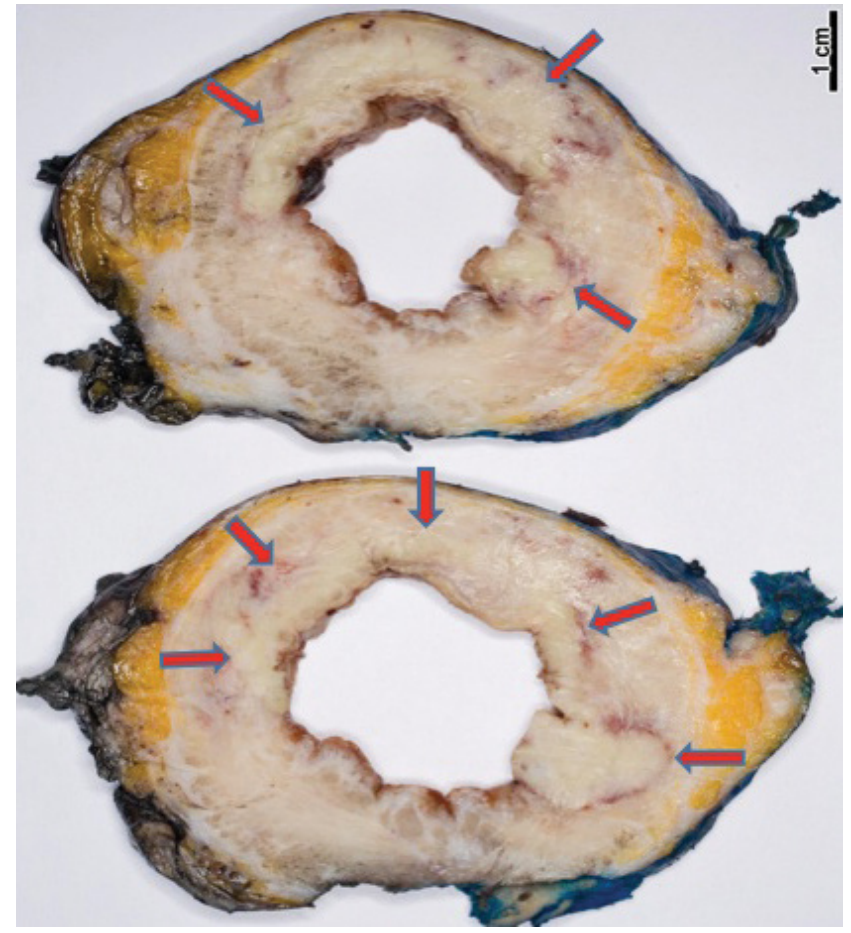

5. ábra

A makroblokkok formájában egészében feldolgozott minta harántszeleteiben jól látható a mély izomrétegbe terjedő vérzéses szegéllyel övezett kiterjedt nekrózis. A vörös nyilak a nekrózis szélét jelölik

neti egyoldali nephrostoma az azotaemián, a pangáson és a vérzésen sem segített. A katéterezések miatt húgyúti fertőzés, lázas állapot jelentkezett, emiatt antibiotikum adása vált szükségessé. 2011. augusztusban, uralhatatlan vérzés és zsugorhólyag miatt, radikális cystectomia vált szükségessé ileum conduit képzésével. A szövődmények a besugárzás - hólyagnekrózis - vérzés - zsugorhólyag - vesepangás láncolataként foglalhatók össze. A vesefunkció romlásában fokozatosan kialakuló KimmelstielWilson-szindróma is állhatott, mivel a pangás mértéke és a vesemúködés gyors romlása aránytalanságot mutatott, párhuzamosan folyamatosan romlott a diabetes is. A kismedencében a korai posztoperatív szakban tályog képződött, ezt feltárás megoldotta. A hólyagban a makroblok- 


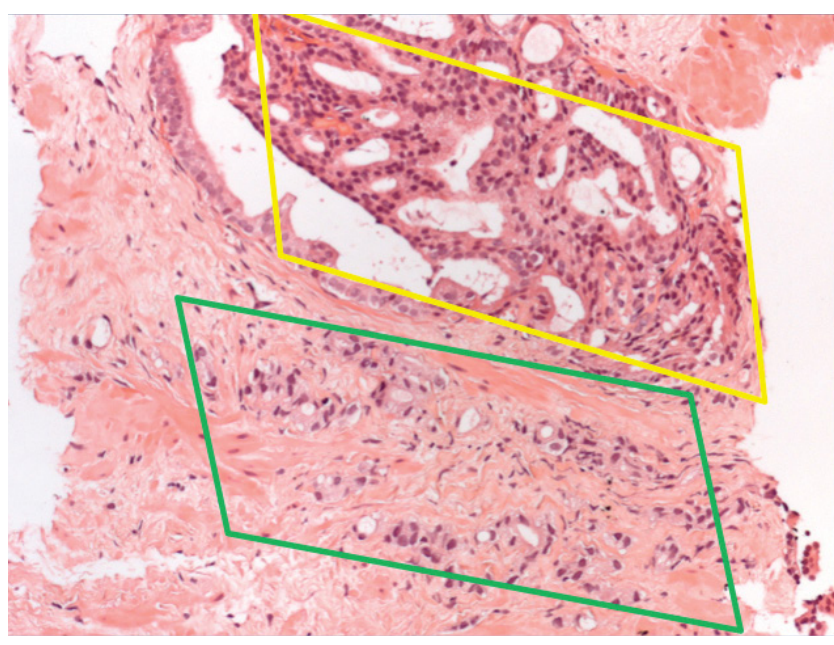

6. ábra

A túbiopsziás minta sárgával határolt területén cribriform, zölddel jelzetten pedig Gleason szerinti 5-ös mintázatot ábrázoló individuális sejtinfiltráció látható, emiatt a korábbi klasszifikáció szerinti Gleason-féle $3+4$ érték $4+5$-ként definiálandó

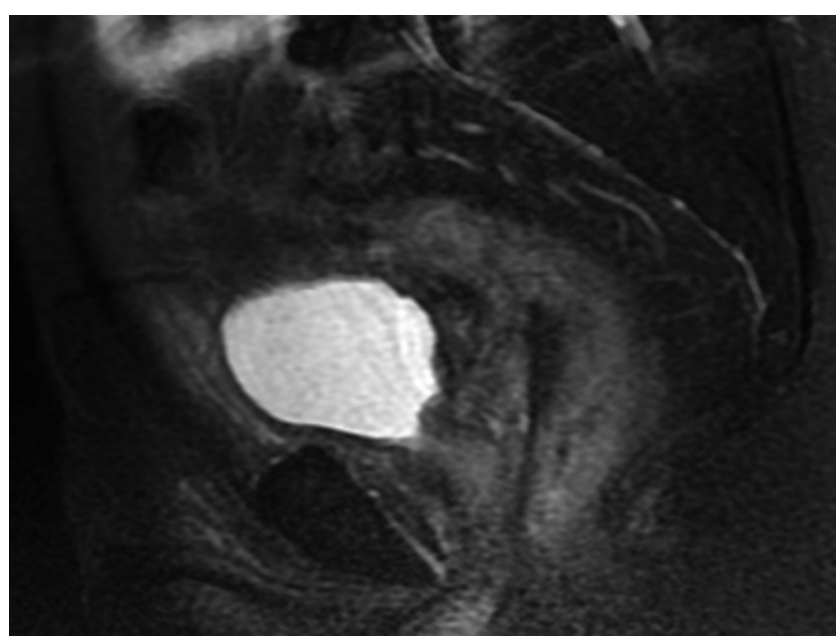

7. ábra | A kiindulási MRI a hólyagdiverticulummal

kos feldolgozással [23] elkészített szövettani vizsgálat kiterjedt körkörös nekrózist mutatott (5. ábra). Közben a szérumkreatinin tovább emelkedett, $1000 \mathrm{mmol} / \mathrm{l}$ fölé, így rendszeres múvesekezelés vált szükségessé, mely azóta is folyik. A pangás csökkent, de a vizelettermelődés is: a stomán át csak néhány száz ml vizelet ürült.

\section{A második beteg}

Kiindulási adatok: A 65 éves beteg minimális vizelési panaszok miatt jelentkezett 2011 májusában az Urológián. A PSA $1,84 \mathrm{ng} / \mathrm{ml}$ volt, a TRUH negatív, viszont a porckemény, gesztenyényi méretű tapintási lelet prosztatarák gyanúját vetette fel. A biopsziás minták a bal oldalon 3\%-ban, a jobb oldalon 25\%-ban tartalmaztak rákos sejteket, a Gleason-érték $3+4=7$ volt, perineuralis terjedés nélkül (6. ábra). A kiindulási stádium T2c volt a patológiai stádium alapján. A stádium pontosítására CT és MRI készült, melyek szerint a vesékben minimális pangás volt, az uréterek torlódtak, sőt a hólyagból diverticulum nyílt; a prosztatában egyértelmú daganat nem volt kimutatható, ahogyan prosztatatokon túli terjedés, illetve zsugorhólyag sem (7. ábra). A diverticulum mellett a TUR után retenció nem volt, csak a vérzések során az alvadékok ürülése miatt. A csontszcintigráfián metasztázis nem igazolódott, az L I-es csigolya ék alakban öszszeroppant.

Terápiás döntés: Részletes felvilágosítás után a beteg a definitív besugárzást választotta, mely előtt 2 hónapos neoadjuváns hormonkezelésben részesült. 2011 . novemberben $25 \times 2$ Gy külső irradiációt kapott lineáris gyorsítóval, 3 dimenziós (3D) konformális technikával a prosztata és a vesicula seminalisok prosztatához közeli harmadának a területére. A külső besugárzás során a periprostaticus, obturator nyirokcsomók és a hólyag alapja az alkalmazott biztonsági zóna miatt a tervezési targetvolumenbe került (a hólyag átlagos besugárzási dózisa 46 Gy, a hólyag maximális dózisa 71 Gy, a hólyagvolumen 50\%-a 42 Gy dózisban részesült). Brachytherapiás boost kezelést terveztünk a prosztatára, de a beteg akut grade 2 -es vizelési panaszai és cystitise miatt ez nem történhetett meg. A tünetek megszünte után, 3 héttel

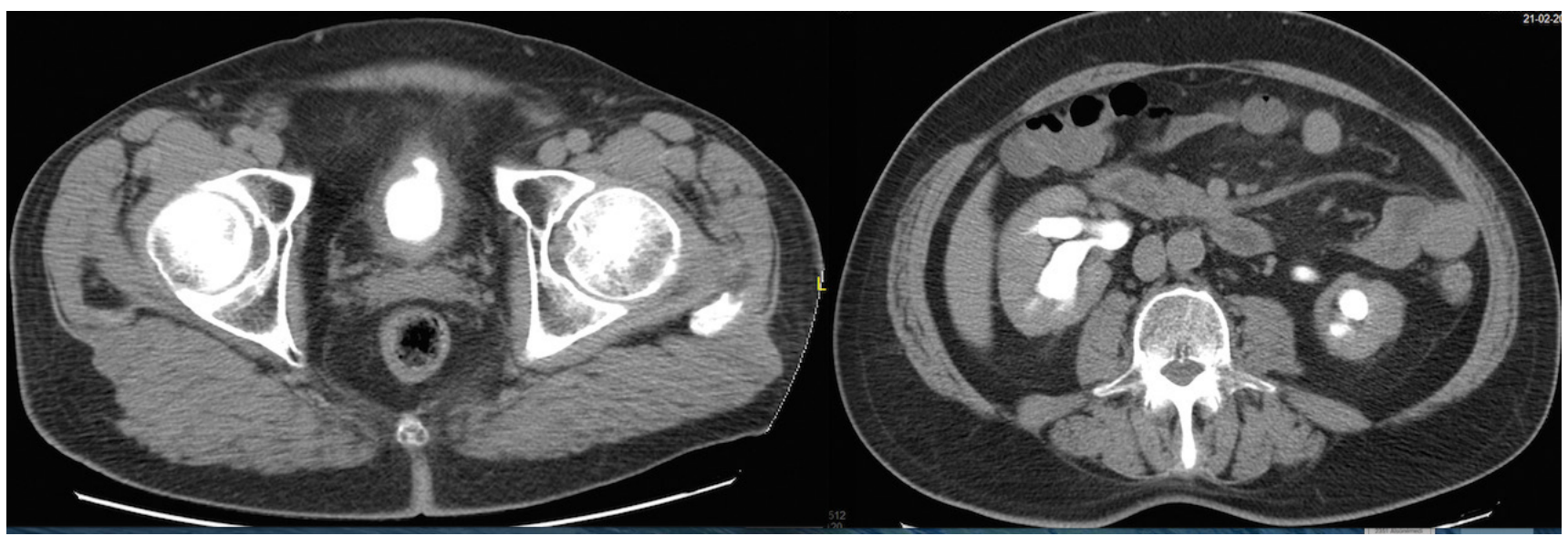

8. ábra

| Besugárzást követő CT-képek a megvastagodott hólyagfallal, a diverticulummal és a veseüregrendszeri tágulattal 


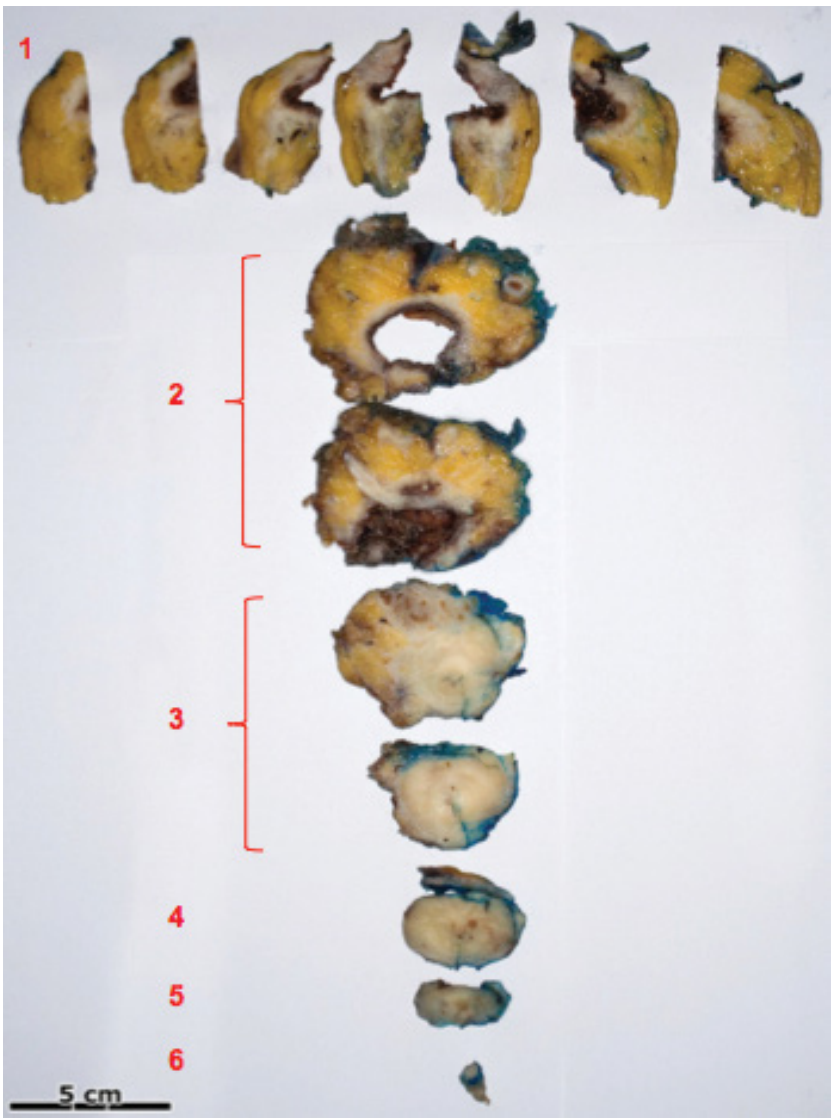

9. ábra

A makroblokkok formájában egészében feldolgozott preparátumban erősen roncsolt, elvékonyodott falú húgyhólyagot és heges hólyagalapot, valamint prosztatát lehet látni. l: vertex, 2 corpus, 3: bázis, 4 : prosztata, 5 prosztataapex, 6 húgycsőcsonk A nyíl az MR-felvételen is látható diverticulumot jelöli

késleltetve 14 × 1,8 Gy teleterápiás dóziskiegészítésben részesült a prosztatára.

Mellékhatások: A kezelés után a vizeletürítés egyre gyakoribbá vált, az ok kiderítésére újabb CT készült, ezen már zsugorhólyag és veseüregrendszeri tágulat látszott (8. ábra). A gyakori vizelés néhány hét alatt teljes incontinentiává alakult. Makroszkópos vérzést a beteg nem észlelt. A mütéti megoldások között felmerült a hólyagaugmentáció, de ezt a besugárzott hátsó húgycső és az alapbetegség miatt elvetettük. 2014. áprilisban radikális cystectomia és ileum conduit készült. A mútét szövődmény nélkül zajlott le, a beteg rendszeres ellenőrzésre jár, elégedett a helyzettel, a kontroll-CT szerint a vesékben a pangás megszünt. A szövettan szerint daganat sem a prosztatában, sem a hólyagban nem volt kimutatható. A makroblokkos technika azonosította a diverticulumnak megfelelő roncsolt területet (9. ábra).

\section{Eredmények}

Mindkét beteg a szövettanilag igazolt prostataadenocarcinoma miatt még hagyományos, 3 dimenziós konformális technikával definitív sugárkezelésben részesült, melynek hatására véglegesen meggyógyultak daganatos alapbetegségükből. Az első beteg besugárzást kapott a húgyhólyagra is, azt feltételezve, hogy a prosztatadaganat beszűrte azt, míg a másodiknál ez csak a hólyagalapot érintette a biztonsági zóna kiterjesztése miatt. A PSA alacsony maradt, és a rectalis tapintás sem jelzett nagyméretű folyamatot. Cisztoszkópia egyik esetben sem történt a CT-eredmény megerösítésére.

A szövődmények elhárítására - az első esetben a vérzés megállítására, a második esetben az incontinentia megszüntetésére - a hagyományos eljárások kudarca miatt csak a radikális cystoprostatectomia maradt mint utolsó lehetőség. Az első betegnél az uraemia kifejlődését már nem akadályozta meg, ebben szerepe volt a vérvizelés miatti számtalan katéterezésnek, endoszkópos műtéteknek és az inzulindependens cukorbetegségnek, mert ezek húgyúti fertőzést okoztak vesekárosodással, mely miatt mưvesekezelés vált szükségessé.

\section{Megbeszélés}

Betegeink kezelése óta jelentős technikai fejlődés tapasztalható mind a kivizsgálásban, mind a kezelések lehetőségeiben [24]. A patológiai értékelés finomodik, a diagnosztikában teret hódít az MRI, mely a prosztatadaganatok stádiumának pontosítására rutineljárássá vált [5], így a húgyhólyag- és kismedencei nyirokcsomóstátusz érintettségének kérdése is pontosabban tisztázható. A besugárzási módszerek fejlődésével, modern brachytherapiával, IM-IGRT vagy stereotaxiás technikával a kuratív eredmények javulása mellett a szövődmények további csökkentése válik lehetővé [14-16, 25]. Elméletileg is belátható, hogy teljesen kiküszöbölni a közeli szervek, a végbél, a hátsó húgycső, a hólyag érintettségét lehetetlen, de a lehető legalacsonyabb mértékre lehet leszorítani.

\section{A szövettani diagnózis tanulságai és modern értékelése}

A Gleason-pontszám értékelése az ISUP szempontrendszerének befolyására napjainkra módosult, modern, nagyfokú pontosságra törekszenek, aminek ugyancsak szerepe lehet abban, hogy az optimálisan megválasztott terápia a szövődmények valószínűségét csökkentse. A korábbi Gleason-féle, 2-től 10-ig terjedő skála mellett az ISUP-score-rendszer 5 pontos skála, mely sok értékes látásmódot vett át a régebbi időkből. A szövettani leletben mindkét score megadása javasolt, az utóbbi segíti az előbbi értelmezését. A Gleason szerinti 2-t ma már adenomának tekintjük, a definitív adenocarcinomák zöme a Gleason-féle 6-10 közötti sávba tartozik. Hangsúlyos elem volt eddig is a Gleason-érték első száma, a domináns növekedési mintázat, mely megfelelő mintakiterjedést igényel. A klinikai lefolyást azonban jobban tükrözi emellett a második szám, mely a legkevésbé differenciált mintázatot jelenti napjainkban, bármilyen kicsi kiterje- 
désben van is jelen (szemben a korábbi második domináns mintázattal). A cribriform komponens jelenlétét kedvezőtlen prognosztikai eredményei miatt ma a korábbi Gleason-féle 3 helyett 4-nek kell tekinteni [10].

Mindezek alapján első esetünk $2+3=5$ pontszámértéke a jelenlegi szemlélet szerint $3+4=7$ lenne, ahogyan második esetünkben a 2011-ben megállapított Gleason-féle $3+4$ érték a cribriform domináns mintázat és az 5\% alatti Gleason szerinti 5-ös komponens miatt az új megközelítésben $4+5=9$ lenne. Mindkét beteg esetében a modern ISUP-score-rendszer alapján rizikóemelkedést detektálhatunk. Az új szemléletű Gleasonpontozás differenciáltabb betegbesorolást tesz lehetővé:

Gleason-érték max. 6 = ISUP 1/5: alacsony rizikójú csoport;

Gleason-érték 7 , amely lehet ISUP $2 / 5$ vagy $3 / 5$ : közepes rizikójú csoport;

Gleason-érték 8 vagy több, amely lehet ISUP 4/5 vagy 5/5: magas rizikójú csoport.

\section{A képalkotó diagnózis tanulságai és modern stratégiái}

A PC lokális stádiumának, a prosztata tokján belüli, illetve azon túli terjedésének megállapítására, a T2-es és T3as stádiumú daganatok elkülönítésére a TRUH- vagy CT-alapú vizsgálómódszerek nem optimálisak [26]. A legérzékenyebb képalkotó módszere az mpMRI. Bár az MRI szövettanilag nem igazolhatja a rák jelenlétét, mégis alkalmas a PC gyanújának detektálására és ismert daganat esetén a stádium pontosítására. Az amerikai és európai uroradiológiai munkacsoportok (ACR - American College of Radiology; ESUR - European Society of Uroradiology; AdMeTech Foundation) 2015-ben konszenzust fogalmaztak meg az mpMRI alkalmazásáról [27], melyben ötpontos skálát definiáltak a klinikailag valószínútlen prosztatarák radiológiai képétől a daganat gyanújáig. Az MRI időzítése a biopszia után leghamarabb 6 héttel javasolt a posztbiopsziás vérzés zavaró eredményének kiküszöbölésére. Magas kockázatú betegekben a nyirokcsomók vizsgálata MR-limfográfiával, diffúziósúlyozott MRI-vel további segítséget nyújthat [28].

\section{A sugárterápia tanulságai és modern stratégiái}

Ma már intenzitásmodulált-képvezérelt besugárzási módszert alkalmaznak csaknem minden hazai sugárterápiás központban, mellyel a védendő szervek dózisterhelése jelentősen csökkenthető, s csaknem minden stádiumú lokalizált prosztatadaganattal rendelkező beteg ellátható $[4,15,16]$. A szövődmények aránya is javult, de teljesen nem tüntek el.

A korábban alkalmazott konformális besugárzás módszerével a betegek beállításából és a szervek elmozdulásából adódó szükséges biztonsági zónák a kijelölt dagana- tos céltérfogatok körül 1-2 cm-es méretúek voltak a tumor megfelelő ellátásához. Napjaink modern módszereivel, mint például a cyberkés, stereotaxiás ívbesugárzások, a prosztatába helyezett aranymarkerek mellett néhány milliméteresre csökkent ez a margó, így sugársebészeti dózisok kiszolgáltatása ellenére a következményes mellékhatások is redukálhatók lettek [14, 29, 30]. A bemutatott esetek kapcsán mpMRI-diagnosztikát követően a prosztata (és a vesicula seminalisok) körüli, valamint a hólyagra terjedő folyamatnál a makroszkópos folyamatra is kiterjesztve (centrumonként validált mérések alapján meghatározott) néhány mm-es biztonsági zóna alkalmazása lehetôvé tette volna a húgyhólyag kíméletét, különösen aranymarker-implantációt követően. Napjainkban a kismedencei nyirokrégió besugárzásának indikációja vitatott magas rizikójú esetekben, de annak volumene és toxicitása is jelentősen kedvezőbb a modern radioterápiás módszerekkel [31].

\section{A mellékhatások tanulságai és értékelésük}

Az anatómiai elhelyezkedésből következik, hogy a leggyakoribb sugárterápiás mellékhatások két nagy csoportra oszthatók, a gastrointestinalis és az urogenitalis szövődményekre. Lefolyásuk korai és késői lehet, attól függően, hogy az első 90 napon belül vagy hónapok, akár évek múltán mutatkoznak. A bélszövődmények a leggyakrabban a végbél gyulladását jelentik, gyakori fájdalmas székletürítéssel, ritkábban véres széklet formájában. Hólyaggyulladás esetén tipikus jel a gyakori fájdalmas, néha véres vizelés. A vérkép és a bőr romlásának klinikai jelei ritkán jelentkeznek [32]. A heveny szövődmények tüneti kezeléssel enyhíthetők, a tünetek néhány hét (hónap) után spontán elmúlnak. A késői szövődmények között szerepelhet az impotencia, ez a betegek 60\%-át érinti (az ADT hatása nélkül), de ez is sokkal kevesebb, mint mútét után [32]. Kockázatos lehet a hátsó húgycső szúkülete, a hólyagmúködés csökkenése [33] és a zsugorhólyag, mert e betegségek nehezen gyógyíthatók, sokszor azok is csak ismételt mütétek árán. Ismert ezen beavatkozások kockázata, csonkoló jellege, mégis kényszerhelyzetben csak ez bizonyul az egyetlen megoldásnak. A mellékhatások mértékét 1-tôl 5-ig fokozatokra osztjuk [22]. A gyakorlatban a legtöbb szövődmény 1-es, illetve 2-es fokozatú. A heveny és zavaró szövődmények előrevetíthetik a késő szövődmények veszélyét, ezért már ezek jelentkezésekor érdemes a beteg besugárzási tervének ellenőrzése, szükség esetén esetleges korrekciója $[34,35]$. Az ismertetett esetekben mindkét betegnél grade 2 -es akut cystitises mellékhatások jelentkeztek már a besugárzás 2/3-ánál. Az első betegnél a kiterjedt hólyagérintettség [36], a másodiknál esetlegesen a hólyagdiverticulum, valamint a szövődményláncolat okozhatta a magasabb fokozatú késői toxicitási arányt [37]. 


\section{Következtetések}

A magyar irodalomban nem találkoztunk olyan beszámolóval, amikor hólyagvérzés vagy zsugorhólyag miatt kényszerből radikális cystectomia történt volna. Eseteink részletes elemzésével próbáltuk megtalálni azokat a tényezőket, amelyek idáig vezettek. Ennek kapcsán áttekintettük a PC kórismézésének és kezelésének, több szakma területét átfogó fejlődésének lépeseit, és úgy foglaltuk össze azokat, hogy a figyelmet a mellékhatások csökkentésének lehetőségére irányítsuk.

Eseteink kapcsán levezettük, hogy a problémák egy része a technikai fejlődéssel mára megoldódott. Napjainkban a kivizsgálás során az MRI a diagnosztikus vizsgálatok része. A modern patológiai leletek pontosabb prognosztikai besorolást tesznek lehetővé. A sugárterápia technikai javulása szúkebb biztonsági zóna alkalmazását, következményesen a védendő szervek besugárzási dózisának és a mellékhatásoknak a csökkenését eredményezik.

Meglátásunk szerint az onkoteam döntéseit javasolt lenne kiterjeszteni nemcsak a beavatkozások indikálására, hanem azok technikai kivitelezésére is. Ehhez azonban szükség van a multidiszciplináris aspektusból áttekintett ismeretekre, amelyek nemcsak a hatékonyság javítására, hanem a súlyos szövődmények elkerülésére is jobban fókuszálnak.

Anyagi támogatás: A munka megjelenését a MolMedEx TUMORDNS (GINOP-2.3.2-15-2016-00020) pályázat támogatta.

Szerzői munkamegosztás: V. L., R. J., M. A. a közlemény általános onkológiai, radiológiai és sugárterápiás aspektusait, valamint az ezekhez kapcsolódó képi dokumentáció előkészítését, B. Z., P. L. az urológiai szempontokat, S. F. a patológiai összefoglalást és a szövettani képanyagot készítette. M. A., S. F. irányította a kézirat kialakítását, részvételük egyenlő mértékü a munkában. A cikk végleges változatát valamennyi szerző elolvasta és jóváhagyta.

\section{Érdekeltségek: A szerzőknek nincsenek érdekeltségeik.}

\section{Irodalom}

[1] Kásler M, Ottó Sz, Kenessey I. The current situation of cancer morbidity and mortality in the light of the National Cancer Registry, Hungary. [A rákmorbiditás és -mortalitás jelenlegi helyzete a Nemzeti Rákregiszter tükrében.] Orv Hetil. 2017; 158: 8489. [Hungarian]

[2] Bíró K, Géczi L. Epidemiology and etiology of prostate cancer. In: Géczi L, Kásler M. (eds.) Prostate cancer. [Prosztatarák epidemiológiája és etiológiája. In: Géczi L, Kásler M. (szerk.) Prosztatarák.] Zafír Press, Budapest, 2014; pp. 3-5. [Hungarian]

[3] Bodoky Gy. Epidemiology and screening. In: Bodoky Gy, Kopper L. (eds.) Urogenital oncology. [Epidemiológia és szürés. In: Bodoky Gy, Kopper L. (szerk.) Urogenitális onkológia.] Medicina Könyvkiadó, Budapest, 2011; pp. 122-183. [Hungarian]
[4] Mottet N, Bellmunt J, Briers E, et al. EAU-ESTRO-SIOG Guidelines on Prostate Cancer. Available from: https://uroweb. org/wp-content/uploads/EAU-Guidelines-Prostate-Cancer-2016.pdf [accessed: May 31, 2018].

[5] de Rooij M, Hamoen EH, Witjes JA, et al. Accuracy of magnetic resonance imaging for local staging of prostate cancer: A diagnostic meta-analysis. Eur Urol. 2016; 70: 233-245.

[6] Schwarzenböck S, Souvatzoglou M, Krause BJ. Choline PET and $\mathrm{PET} / \mathrm{CT}$ in primary diagnosis and staging of prostate cancer. Theranostics 2012; 2: 318-330.

[7] Goldstein J, Even-Sapir E, Ben-Haim S, et al. Does choline PET/CT change the management of prostate cancer patients with biochemical failure? Am J Clin Oncol. 2017; 40: 256-259.

[8] Sasikumar A. Specificity of ${ }^{68} \mathrm{Ga}$-PSMA PET/CT for prostate cancer - myths and reality. Indian J Nucl Med. 2017; 32: 11-12.

[9] Rauscher I, Maurer T, Fendler WP, et al. ${ }^{68} \mathrm{Ga}$-PSMA ligand $\mathrm{PET} / \mathrm{CT}$ in patients with prostate cancer: How we review and report. Cancer Imaging 2016; 16: 14.

[10] Epstein JI, Zelefsky MJ, Sjoberg DD, et al. A contemporary prostate cancer grading system: a validated alternative to the Gleason score. Eur Urol. 2016; 69: 428-435.

[11] Gill IS, Zippe CD. Laparoscopic radical prostatectomy: technique. Urol Clin North Am. 2001; 28: 423-436.

[12] Rassweiler J, Hruza M, Teber D, et al. Laparoscopic and robotic assisted radical prostatectomy - critical analysis of the results. Eur Urol. 2006; 49: 612-624.

[13] Hamilton ZA, Kane CJ. Nerve-sparing technique during radical prostatectomy and its effect on urinary continence. Eur Urol. 2016; 69: 590-591.

[14] Detti B, Bonomo P, Masi L, et al. Cyberknife treatment for low and intermediate risk prostate cancer. Cancer Invest. 2015; 33: 188-192.

[15] Biegała M, Hydzik A. Analysis of dose distribution in organs at risk in patients with prostate cancer treated with the intensitymodulated radiation therapy and arc technique. J Med Phys. 2016; 41: 198-204.

[16] Das S, Liu T, Jani AB, et al. Comparison of image-guided radiotherapy technologies for prostate cancer. Am J Clin Oncol. 2014; 37: 616-623.

[17] Hamdy FC, Donovan JL, Lane JA, et al. 10-year outcomes after monitoring, surgery, or radiotherapy for localized prostate cancer. N Engl J Med. 2016; 375: 1415-1424.

[18] Messing EM, Manola J, Yao J, et al. Immediate versus deferred androgen deprivation treatment in patients with node-positive prostate cancer after radical prostatectomy and pelvic lymphadenectomy. Lancet Oncol. 2006; 7: 472-479.

[19] Yossepowitch O, Eggener SE, Serio AM, et al. Secondary therapy, metastatic progression, and cancer-specific mortality in men with clinically high-risk prostate cancer treated with radical prostatectomy. Eur Urol. 2008; 53: 950-959.

[20] Chang K, Qin XJ, Zhang HL, et al. Comparison of two adjuvant hormone therapy regimens in patients with high-risk localized prostate cancer after radical prostatectomy: primary results of study CU1005. Asian J Androl. 2016; 18: 452-455.

[21] Buyyounouski MK, Choyke PL, McKenney JK, et al. Prostate cancer - major changes in the American Joint Committee on Cancer eighth edition cancer staging manual. CA Cancer J Clin. 2017; 67: 245-253.

[22] Common Terminology Criteria for Adverse Events (CTCAE) v4.0. Published: May 28, 2009 (v4.03: June 14, 2010). Available from: https://evs.nci.nih.gov/ftpl/CTCAE/CTCAE_ 4.03/CTCAE_4.03_2010-06-14_QuickReference_8.5x11.pdf

[23] Sükösd F, Ivanyi B, Pajor L. Accurate determination of the pathological stage with gross dissection protocol for radical cystectomy. Pathol Oncol Res. 2014; 20: 677-685.

[24] Riesz P, Nyírády P. Novelties in diagnostics and treatment of prostate cancer. [Újdonságok a prosztatarák diagnosztikájában és kezelésében.] Orv Hetil. 2016; 157: 410-414. [Hungarian] 
[25] Bottomley D, Ash D, Al-Qaisieh B, et al. Side effects of permanent I125 prostate seed implants in 667 patients treated in Leeds. Radiother Oncol. 2007; 82: 46-49.

[26] Mitterberger M, Pinggera GM, Pallwein L, et al. The value of three-dimensional transrectal ultrasonography in staging prostate cancer. BJU Int. 2007; 100: 47-50.

[27] Weinreb JC, Barentsz JO, Choyke PL, et al. PI-RADS prostate imaging - reporting and data system: 2015, Version 2. Eur Urol. 2016; 69: 16-40.

[28] Fortuin A, de Rooij M, Zamecnik P, et al. Molecular and functional imaging for detection of lymph node metastases in prostate cancer. Int J Mol Sci. 2013; 14: 13842-13857.

[29] Syed YA, Patel-Yadav AK, Rivers C, et al. Stereotactic radiotherapy for prostate cancer: a review and future directions. World J Clin Oncol. 2017; 8: 389-397.

[30] Jorgo K, Ágoston P, Major T, et al. Transperineal gold marker implantation for image-guided external beam radiotherapy of prostate cancer: A single institution, prospective study. Strahlenther Onkol. 2017; 193: 452-458.

[31] Pommier P, Chabaud S, Lagrange JL, et al. Is there a role for pelvic irradiation in localized prostate adenocarcinoma? Update of the long-term survival results of the GETUG-01 randomized study. Int J Radiat Oncol Biol Phys. 2016; 96: 759-769.

[32] Nilsson S, Norlén BJ, Widmark A. A systematic overview of radiation therapy effects in prostate cancer. Acta Oncol. 2004; 43: 316-381
[33] Ghirca MV, Chibelean C, Frunda EA, et al. The importance of bladder contractility index in the management of underactive bladder. [A hólyagkontraktilitási index meghatározásának fontossága a csökkent hólyagmúködés kezelésében.] Orv Hetil. 2017; 158: 1222-1227. [Hungarian]

[34] Peach MS, Showalter TN, Ohri N. Systematic review of the relationship between acute and late gastrointestinal toxicity after radiotherapy for prostate cancer. Prostate Cancer 2015; 2015: 624736.

[35] Jereczek-Fossa BA, Zerini D, Fodor C, et al. Correlation between acute and late toxicity in 973 prostate cancer patients treated with three-dimensional conformal external beam radiotherapy. Int J Radiat Oncol Biol Phys. 2010; 78: 26-34.

[36] Improta I, Palorini F, Cozzarini C, et al. Bladder spatial-dose descriptors correlate with acute urinary toxicity after radiation therapy for prostate cancer. Phys Med. 2016; 32: 1681-1689.

[37] Nishimura T, Suzuki K, Iijima M, et al. Spontaneous rupture of bladder diverticulum after postoperative radiotherapy for carcinoma of the uterine cervix: case report. Radiat Med. 2000; 18: 261-265.

\section{Arbeiten Sie als Arzt für den ADAC Ambulance-Service!}

\section{Dolgozzon orvosként az ADAC ambuláns segélyszolgálatnál!}

(Maráz Anikó dr., Szeged, Korányi fasor 12., 6720 e-mail: dr.aniko.maraz@gmail.com)

Der ADAC Ambulance-Service unterstützt seine Versicherten im Falle einer medizinischen Notlage im Ausland. Für diesen Bereich suchen wir Ärzte, die für uns freiberuflich Fälle abklären möchten.

Az ADAC ambuláns segélyszolgálat segítséget nyújt biztosított tagjainak küldöldi egészségügyi szükséghelyzetekben. Szabadfolglalkozású orvosokat keresünk a szolgálat keretében felmerült feladatok elláááara.

Als unser Vertragsarzt treten Sie im Falle einer Krankenhausbehandlung eines unserer Versicherten mit den behandelnden Ärzten in Ungarn in Kontakt. Sie erfragen Diagnosen, Verfassung, Versorgung und Prognose des Patienten und bewerten die Modalitäten eines Krankenrücktransports nach Deutschland. Diese Informationen dokumentieren Sie in deutscher Sprache in unserem Online Tool und erstellen einen Medical Report. Sie werden pro Patient mit einer Fallpauschale vergütet.

Für diese Aufgabe verfügen Sie über Kenntnisse der Allgemeinmedizin und besitzen die ärztliche Approbation. Die deutsche Sprache beherrschen Sie sicher in Wort und Schrift.

Haben wir Ihr Interesse geweckt? Dann freuen wir uns auf Ihre Bewerbung!

Für Fragen wenden Sie sich bitte an Angela Lechermann, nwm@adac.de, Telefon: + 49 - 89 - 76764678. 